\title{
The Impact of CRM Strategy on Customer Loyalty in SMEs
}

\author{
Lena Saleh ${ }^{1} \&$ Laura El Saheli ${ }^{1}$ \\ ${ }^{1}$ Faculty of Economic Science and Business Administration, Lebanese University, Beirut, Lebanon \\ Correspondence: Lena Saleh, Faculty of Economic Science and Business Administration, Lebanese University, \\ Beirut, Lebanon.
}

Received: August 2, 2018

Accepted: September 27, 2018

Online Published: October 11, 2018

doi:10.5539/ibr.v11n11p37

URL: https://doi.org/10.5539/ibr.v11n11p37

\begin{abstract}
The beauty service industry is one of the most flourishing industries in contemporary Beirut, the capital of Lebanon, as versatile demands from men and women have catered to this uplifting growth. A national scandal, however, lead to the suspension of several beauty centers, and conveyed a challenge for competitive small-medium enterprises (SME) to sustain relationships with customers over the long-run. The aim of this study was to understand the impact of customer relationship management (CRM) strategy on customer loyalty using the case of beauty centers in Beirut, Lebanon. The study employed a quantitative approach where data was collected by means of a questionnaire, from a sample of 103 customers. Four variables, as components of CRM, were measured in this study. Results of the statistical analysis verified that customer experience, employee behaviour, and value proposition have a positive impact on customer loyalty. This research provides recommendations for strategically improving relationship-oriented practices in Lebanese SMEs, particularly in the beauty sector.
\end{abstract}

Keywords: Small-Medium Enterprise (SME), Customer Relationship Management (CRM), Customer Loyalty, Beauty Center

\section{Introduction}

Rapid changes in the competitive environment have forced enterprises to rethink the way they do business. In many contemporary societies, the reputation and importance of beauty has materialized into elective forms of cosmetic enhancements and the marketing of 'the self' as a commodity for visual consumption for a wide range of people. Hence, the demand for beauty-enhancing services rises, as long as the desire to attain certain aesthetic ideals persists in society. In response to the demand, the supply for such services is multiplying, meaning that competition among small-medium sized enterprises (SMEs) in the market is stiff. This can potentially instigate switching behaviour of customers that want the best value they can get, given that their alternatives are abundant and easily accessible. Thus, the challenge for SMEs is to stand out as the best-option in order to retain a good customer base and seize their loyalty. The focus of this paper is on SMEs, and how customer relationship management (CRM) is considered an effective and strategic option to gain a competitive advantage. Previous studies have looked into the attainment of customer loyalty by way of relationship-oriented practices, such as CRM, but in the financial sector. This study looks at the Beauty sector, and aims to discover to what extent are SMEs (Beauty Centers) in Beirut, implementing the CRM strategy and the impact of CRM on customer loyalty.

\section{Literature Review}

\subsection{SME and CRM}

Being customer-driven is the main survival tool for any enterprise in a competitive market. After all, the customer is the central player in every business venture. Large or small, the purpose of every enterprise is not just to earn a profit, but instead, to create and keep a customer (Scarborough, 2011).Thus, the way that SMEs compete in today's economy is significantly due to the range of challenges they face in their ability to maintain a significant customer base (Harrigan et al., 2011). Today most Lebanese SMEs face significant challenges in breaking the barriers of growth and face a high risk for long-term sustainability, especially as they are situated in a complex environment. Lebanon also suffers overall from a poor infrastructure setup, economic uncertainty, and slow business activity. As a result, enterprises are forced to keep up with changing demands over time and break traditional means of doing business in order to survive in the market. Khodakarami \& Chan (2014) elaborate the application of customer relationship management, as a major component of success for many enterprises that 
desired to shift away from traditional approaches. The following table presents the difference of CRM with traditional marketing initiatives.

Table 1. Traditional Marketing versus CRM Approach

\begin{tabular}{cc}
\hline Traditional Marketing & Customer Relationship Management \\
\hline Transaction focus & Customer focus \\
Short-term focus & Lifetime focus \\
One transaction & Multiple transactions \\
Broadcast approach & Sniper approach \\
One-way, one-time communication & Two-way, continuous dialogue \\
Segment of many & Segment of one \\
\hline
\end{tabular}

Source: Piccoli et al., (2003) p.62, as cited in Ozgener \& Iraz (2006)

From the overall evaluation of the topic it has been recognized that the purpose of CRM is to develop customers instead of just focusing on earning profit. According to Piroozfar \&Yaghini (2012), high competition and decreasing customer loyalty for businesses leads to the emergence of business models that concentrate on nurturing relationships with customers.

\subsection{The Role of CRM in Attaining Customer Loyalty}

Implementing a CRM strategy is a complex undertaking that requires effort across the entire organization. Organizations that strive for a relationship aim for the long-term, and have a deep interest in the "right" customers (Peelen \& Beltman, 2013). However, building relationships requires a business strategy and an inclusive vision throughout the entire organization, as it affects every function. Without this vision, the enterprise will not stand out from competition, customers will not know what to expect, and employees would be lost in terms of what to deliver to the customer's experience with the business (Gartner, 2001).

Customer loyalty is a competitive asset for any enterprise and has emerged as a key driver of profitability, given that loyal customers tend to purchase more (Shen \& Russell, 2007). It is assumed that the cost of retaining a loyal (existing) customer is five times less than the cost of attracting and serving a new one (Ndubisi et al., 2007; Peelen, 2013; Reijonen \& Laukkanen, 2010). Thus, higher customer traffic leads to higher profitability and greater market share for the business (Oliver, 1999). However, for a consumer to become and remain loyal, he or she must believe that the firm offers the best choice alternative (Oliver, 1999). The implementation of CRM strategies not only improves retention rates but also spending. Hence, the potential for developing meaningful relationships becomes greater than ever when efficient methods-are used to capitalise on customer needs and preferences.

The discussion of CRM and its effect on customer loyalty has been the focus of a number of previous studies. Table (2) below summarizes the most important studies related to the relationship between CRM and Customer loyalty The studies commonly recognize that CRM offers the necessary tools to gather relevant data quickly, identify the most valuable customers over time, and increase customer loyalty through customized products and services. 
Table 2. Previous studies on CRM \& Customer Loyalty

\begin{tabular}{|c|c|c|c|}
\hline Author(s) & Objective & Methodology & Results \\
\hline $\begin{array}{l}\text { (Shen \& } \\
\text { Russell, } \\
\text { 2007) }\end{array}$ & $\begin{array}{l}\text { To examine the relationship between } \\
\text { CRM practices in customer service } \\
\text { and customization, multiple channels } \\
\text { and customer loyalty, and the } \\
\text { moderating effect the multiple } \\
\text { channels have on the relationships } \\
\text { between CRM practices and customer } \\
\text { loyalty. }\end{array}$ & $\begin{array}{l}\text { Survey on financial } \\
\text { consumers in Taiwan; } 400 \\
\text { questionnaires distributed, } \\
\text { response rate of } 63 \% \text {. }\end{array}$ & $\begin{array}{l}\text { CRM practices involving loyalty } \\
\text { programs and cross-selling, customer } \\
\text { service and customization, and the use } \\
\text { of multiple channels have positive } \\
\text { effects on customer loyalty. }\end{array}$ \\
\hline $\begin{array}{l}\text { (Ndubisi et } \\
\text { al, 2007) }\end{array}$ & $\begin{array}{l}\text { To examine the impact of relationship } \\
\text { marketing strategies, including: } \\
\text { commitment, competence, } \\
\text { communication and conflict handling, } \\
\text { on customer loyalty, and the effects of } \\
\text { trust and relationship quality. }\end{array}$ & \begin{tabular}{lr}
\multicolumn{2}{l}{ Survey on bank customers } \\
in Kota & Kinabalu, \\
Malaysia; & 400 \\
questionnaires & were \\
collected, with a response \\
rate of $57.5 \%$
\end{tabular} & $\begin{array}{l}\text { The relationship marketing strategies } \\
\text { are directly and indirectly associated } \\
\text { with customer loyalty (through trust } \\
\text { and relationship quality). Trust and } \\
\text { relationship quality are directly } \\
\text { associated with loyalty. }\end{array}$ \\
\hline $\begin{array}{l}\text { (Fozia et } \\
\text { al., 2014) }\end{array}$ & $\begin{array}{l}\text { To investigate the impact of CRM on } \\
\text { the profitability of Kenyan Public } \\
\text { Universities, and the impact of CRM } \\
\text { on gaining customer loyalty. }\end{array}$ & $\begin{array}{l}\text { Survey of } 100 \text { students } \\
\text { and interview on } 12 \\
\text { university heads; Moi } \\
\text { University, Kenya }\end{array}$ & $\begin{array}{l}\text { CRM strategy has a positive impact for } \\
\text { gaining competitive advantage and } \\
\text { customer loyalty for the University. }\end{array}$ \\
\hline $\begin{array}{l}\text { (Long et } \\
\text { al., 2013) }\end{array}$ & $\begin{array}{l}\text { To examine the impact of CRM } \\
\text { elements on customer satisfaction and } \\
\text { loyalty. }\end{array}$ & $\begin{array}{l}\text { Questionnaire distributed; } \\
300 \text { out of } 500 \text { usable } \\
\text { surveys; at department } \\
\text { store in Tehran, Iran. }\end{array}$ & $\begin{array}{l}\text { CRM has a positive relationship on } \\
\text { satisfaction and loyalty. Employee } \\
\text { behaviour showed the most significant } \\
\text { relation and contribution to customer } \\
\text { satisfaction and loyalty. }\end{array}$ \\
\hline $\begin{array}{l}\text { (Oliver, } \\
\text { 1999) }\end{array}$ & $\begin{array}{l}\text { To discover what aspect of } \\
\text { satisfaction responses have } \\
\text { implications for loyalty, and what } \\
\text { fraction of loyalty is due to this } \\
\text { satisfaction component. }\end{array}$ & $\begin{array}{l}\text { Descriptive } r \text { study; } \\
\text { qualitative review of } \\
\text { literature }\end{array}$ & $\begin{array}{l}\text { Satisfaction is a necessary step in the } \\
\text { formation of loyalty, however, } \\
\text { becomes less significant as loyalty } \\
\text { begins to set through other mechanisms } \\
\text { such as: individual perception, personal } \\
\text { courage, and social bonding. }\end{array}$ \\
\hline $\begin{array}{l}\text { (Colgate \& } \\
\text { Danaher, } \\
2000)\end{array}$ & $\begin{array}{l}\text { To study the effect of implementing } \\
\text { CRM on customer satisfaction and } \\
\text { loyalty in the bank industry. }\end{array}$ & $\begin{array}{l}\text { Quantitative research on } \\
1917 \text { subjects from } \\
\text { telephone directory in } \\
\text { New Zealand; response } \\
\text { rate of } 43.5 \%\end{array}$ & $\begin{array}{l}\text { CRM, carried out skillfully, resulted in } \\
\text { higher satisfaction and loyalty. } \\
\text { Opposite effects were true when CRM } \\
\text { execution was deficient. }\end{array}$ \\
\hline $\begin{array}{l}\text { (Kirmaci, } \\
\text { 2012) }\end{array}$ & $\begin{array}{l}\text { To reveal the relationship between } \\
\text { CRM and the customer loyalty in the } \\
\text { banking sector. }\end{array}$ & $\begin{array}{l}\text { Questionnaire } \\
\text { commercial on } \\
\text { customers of } 23 \text { branches } \\
\text { of Ziraat Bankasi in } \\
\text { Denizli, Turkey. }\end{array}$ & $\begin{array}{l}\text { Customer relationship management has } \\
\text { an effect on customer loyalty in the } \\
\text { banking sector. Collecting customer } \\
\text { information arouses a sense that the } \\
\text { customer is valued. Furthermore, short } \\
\text { waiting times, personnel knowledge, } \\
\text { and speed of service account to } \\
\text { customer loyalty. }\end{array}$ \\
\hline $\begin{array}{l}\text { (Bobalca et } \\
\text { al., 2012) }\end{array}$ & $\begin{array}{l}\text { To develop and test a customer } \\
\text { loyalty scale. The tested hypothesis is } \\
\text { that loyalty is a process with four } \\
\text { phases: cognitive, affective, conative, } \\
\text { and action. }\end{array}$ & $\begin{array}{l}\text { Qualitative and } \\
\text { quantitative research was } \\
\text { used. Sample was } \\
\text { represented by } 676 \text { buyers } \\
\text { of cosmetic products from } \\
\text { direct selling companies. }\end{array}$ & $\begin{array}{l}\text { Statistical analysis proved that the final } \\
\text { scale, made up of the four components } \\
\text { (cognitive, affective, conative, and } \\
\text { action loyalty) can be used to collect } \\
\text { information about customer loyalty } \\
\text { levels and implement efficient CRM } \\
\text { strategies. }\end{array}$ \\
\hline
\end{tabular}

\section{Methodology}

\subsection{The Research Model \& Hypotheses Statements}

According to the literature review, there are many "building blocks" or elements that makeup CRM. However, after an extensive review of literature, the researcher developed the following four elements to apply to the study: customer experience, employee behaviour, value proposition, and relationship development. These variables are abridged factors that deepen the relationship between the customer and the business, and eventually contribute to higher satisfaction and retention of the customer base. The researcher developed a conceptual model that demonstrates the four variables of CRM that affect customer loyalty. The model below guides the premise of this research study. 


\section{CRM}

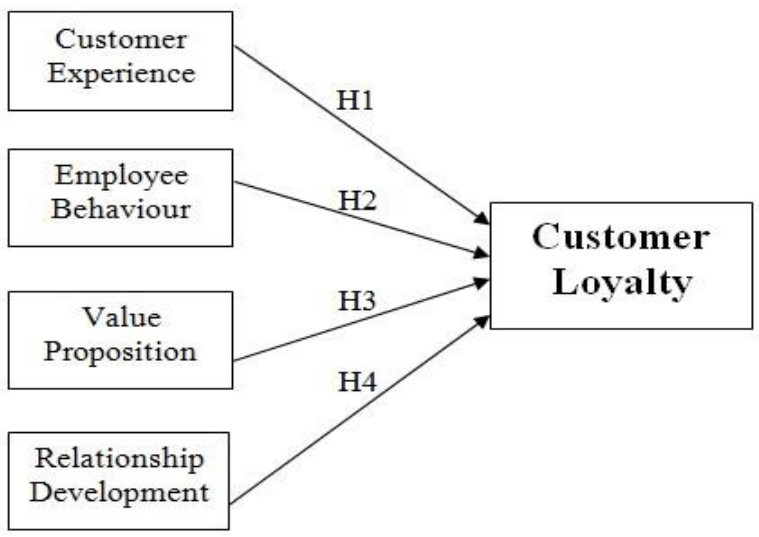

Figure 1. Research Model

The researcher insinuated four hypotheses to this research, as the independent variables were: customer experience; employee behaviour; value proposition; and relationship development. Customer loyalty was the dependent variable. The hypothesis statements were as follows:

H1: Customer experience has a positive impact on customer loyalty.

H2: Employee behaviour has a positive impact on customer loyalty.

H3: Value proposition has a positive impact on customer loyalty.

H4: Relationship development has a positive impact on customer loyalty.

\subsection{Sample Industry}

The researcher targeted a range of 26 popular beauty centers in Beirut. These beauty centers were a collection of small-sized and medium-sized enterprises that employed less than 50 employees or less than 100 employees respectively. The researcher took into consideration that some enterprises held other branches outside of the city; however only the branches in the Beirut region were studied.

\subsection{Design of the Questionnaire}

A questionnaire was the most suitable research instrument to collect quantitative data for the purpose of testing the hypotheses of the study. The questionnaire started with the customer's profile and continued towards specific questions related to variables of the study. The profile section identified the customer's gender, age, marital status, the name of the beauty center they visit, and how often they visit it. The customer' social class, occupation, how much they typically spend for a treatment at the beauty center, and the type of service they purchase were also items of interest in the customer's profile. The next section of the questionnaire contained specific questions pertaining to the variables of the study. The items in the questionnaire for each variable were based on a sufficient literature review of various studies. The items used were inspired by different scales found in the works of Long et al., (2013), Kirmaci (2012), Peelen (2013), Buttler (2004), Fozia et al., (2014), and Bobalca et al., (2012). The researcher did not take a specific scale from any particular source; however, it was suitable for this topic to select and adapt different dimensions from an abundant collection of literature.

For the first independent variable, customer experience, the questionnaire contained eleven items (i.e.: appointment reminder, channel of reminder, appointment follow-up, channel of follow-up, promotion information, channel of promotion information, welcoming reception area, refreshing ambiance, waiting time, hospitality, available help). Employee behaviour was the second independent variable and contained eight items (i.e.: friendliness, politeness, listening to needs, knowing preferences, quick response, knowledge of equipment, expert in work, and cooperativeness). Value proposition, the third independent variable, contained six items (i.e.: fair price, product quality, equipment quality, convenience of location, service-preference fit, fulfillment of needs). Relationship development was the fourth independent variable contained ten items (i.e.: record of personal information, record of visits, presence of a loyalty-card program, complaint, means of reporting complaint, means of handling complaint, satisfaction of solution for complaint, feedback request, channel of feedback request, seriousness for feedback). Using the dimensions of CRM strategy proposed by the literature, 
the researcher adapted six items related to customer loyalty (i.e.: best-choice, emotional attachment, switch-over, re-purchase, satisfaction, and recommendation).

\subsection{Data Collection}

The researcher first made contact with owners of four large beauty centers and requested their consent to share the facility in order to collect data from customers during operating hours. The researcher first contacted two owners through the telephone, and the other two face-to-face, explaining the purpose of the study in detail. However, the researcher's requests were refused by all owners that were approached. Their reasons for refusal involved concerns of privacy and potential disruption to their clientele. This was a limitation in data collection for the study.

Snowball sampling was therefore the most suitable technique to administer the research questionnaire, due to the constraints mentioned, in addition to limited cost and time. There was also no list or obvious sources available to locate specific members of the population needed to contribute to the study, especially after the refusal. Snowball sampling is generally considered a non-probability sampling technique, in which existing study subjects recruit future subjects, from among their acquaintances, via their social networks. This research technique is metaphorically referred to as "snowball" sampling, because as more relationships are built through mutual association, more connections are made so that for information can be shared and collected, similar to a snowball that rolls and increases in size as it collects more snow (Zikmund et al., 2010).

The researcher distributed 110 questionnaires in total, of which 103 were returned completed and usable, and 7 were voided because of incomplete data. This translates to a $94 \%$ response rate. In total, the collected data comprised of responses from 26 different Beauty Centers. The results discuss the descriptive statistics and demographic information in more detail.

\section{Results}

\subsection{Studying the Homogeneity of the Metric Scales}

The metric scales for each variable in the research model are studied in this section to ensure reliability and validity before proceeding with the regression analysis (for hypothesis testing) that will measure the impact of CRM on customer loyalty. To demonstrate the validation of the scales of measurement in this research, the researcher conducted Factor Analysis, and to obtain the reliability of the scales, the researcher conducted the Chronbach Alpha $(\alpha)$ test. Factor analysis is an explorative analysis that reduces a larger set of variables into a smaller set of 'principle components' that account for the variance in the original variables (Zikmund et al., 2010). In this study, principle component analysis (PCA), or factorial analysis, was used as a method for analysing the relationships between the items of a scale, and for the purification and validation of those scales prior to regression analysis. Overall, this analysis, based on the purpose of having homogeneous scales while using methods of measuring dimensions and internal coherence, has enabled the data to be purified and lead to the appropriate structuring of the variables. Thus, the researcher has condensed the variables initially adopted in order to be able to carry out validation tests of the hypotheses. In the table below, the researcher has synthesized the set of items selected as a result of the factorial analysis (PCA and Chronbach $(\alpha)$ ) carried out on the different variables.

\subsection{Regression Analysis}

This section examines the nature of the relationships that characterize the variables under study. The aim is to study the quality of the cause and effect relationships between the independent variables and the dependent variable, formulated in the research hypotheses. Multiple-regression involves predicting the value of the dependent variable based on the values of more than one (multiple) independent variable. Conducting multiple regression analysis as the final step and the purpose was to learn more about the relationship between the variables involved in the research model. Results of this analysis enabled the researcher to discover which independent variable was the best predictor for the dependent variable. The variables entered for the analysis were: customer experience, employee behaviour, value proposition, and relationship development (as independent variables, also called "the predictor variables"); and customer loyalty (the dependent variable, also called "the response variable"). The analysis used a confidence interval of $95 \%$ for the coefficients. Results indicated an $\mathrm{R}$ value of $86 \%$. This value represented the strength of the correlation between the observed and predicted values of the dependent variable. The adjusted $\mathrm{R}^{2}$ had a score of 0.729 . This value meant that $72.9 \%$ of the variability of customer loyalty was accounted for by the model. At the threshold that the (p) value should be 0.05 or less, the table of results indicated which variables were more significant predictors of customer loyalty. The $(\mathrm{p})$ value for customer experience was $=0.000$, and the $(\mathrm{p})$ value for value proposition was $=0.000$, therefore showing a significant relationship. However, employee behaviour, with a (p) value $=0.107$, and 
relationship development with $(\mathrm{p})$ value $=0.174$, showed that there was no significance.

However, it is important to recall that "employee behaviour" was a significant predictor of "customer loyalty" according to the linear regression analysis; while in the multiple regression analysis, the results indicated that it was not. As mentioned earlier, the (p) value of each independent variable indicated whether or not it was a significant predictor of the dependent variable over and above the other independent variables. Hence, this result occurred only because other independent variables were added into the equation. In specific, the variance that the first independent variable shared with the dependent variable overlapped with the variance that was shared between the second, third, and fourth independent variable and the dependent variable. As a result, "employee behaviour" was no longer a unique predictor, and thus did not appear significant in the multiple regression analysis as in the linear regression analysis. Nevertheless, the results of the model still derived a highly significant $\mathrm{R}^{2}$ value, even though some of the independent variables proved insignificant.

Overall, the results of this multiple regression analysis confirmed that CRM has a positive impact on customer loyalty, which was consistent with results of other literature (Colgate \& Danaher (2000); Long et al., (2013), Kirmaci (2012);Fozia et al., (2014); Shen \& Russell (2007).

Table 3. Summary of the variables and items selected as a result of the factorial analysis

\begin{tabular}{ll}
\hline Variable & Items Selected \\
\hline Customer Experience & Welcoming reception \\
& Refreshing ambiance \\
& Generous hospitality \\
Eelp available & Friendly employees \\
& Polite employees \\
& Needs listened \\
& Preferences known \\
& Quick response \\
& Knowledge of equipment \\
& Expert in work \\
& Cooperative employees \\
Value Proposition & Fair price \\
& Product quality \\
& Equipment quality \\
Relationship Development & Service to preference fit \\
& Fulfillment of needs \\
Customer Loyalty & Complaint handled without delay \\
& Satisfaction of solution for complaint \\
& Best choice \\
Satisfaction \\
Attachment \\
No possibility to switch-over \\
\hline
\end{tabular}

Table 4. Results of Multiple Regression Analysis

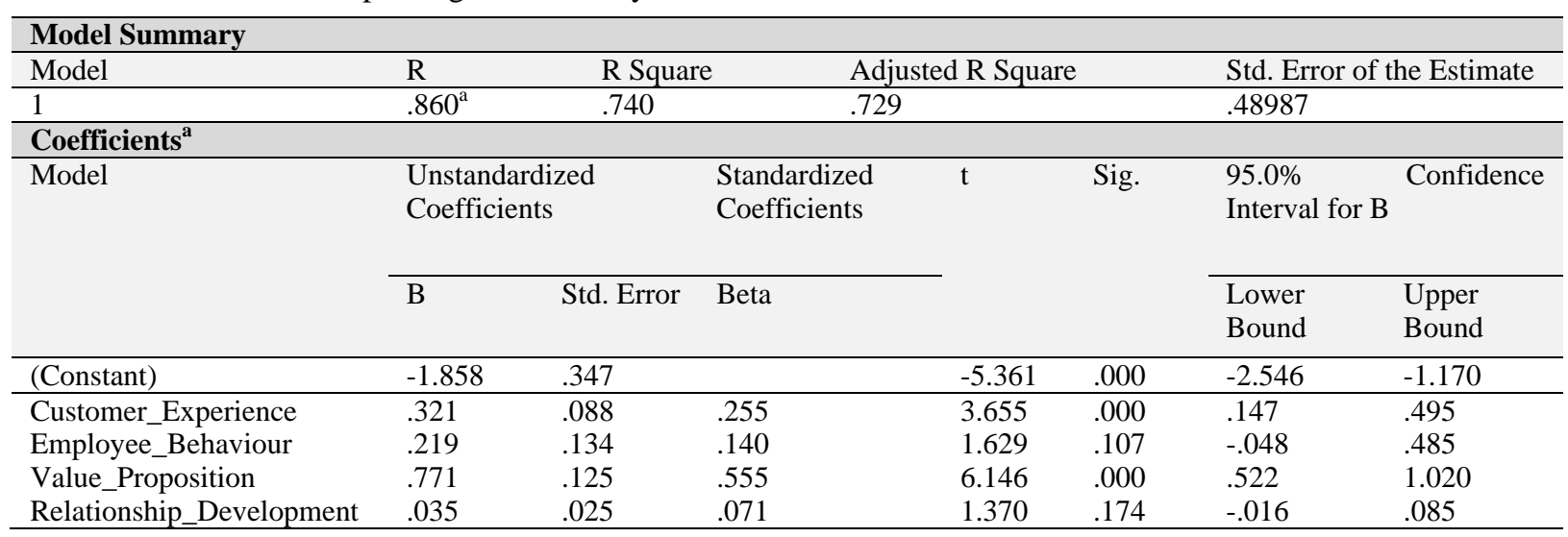

a. Predictors: (Constant), Relationship_Development, Employee_Behaviour, Customer_Experience, Value_Proposition

b. Dependent Variable: Customer_Loyalty

The table below summarizes the results of the hypothesis testing, as a reflection of the outcomes prior to the discussion in the next section. 
Table 4. Summary of Hypothesis Testing

\begin{tabular}{lll}
\hline Hypothesis & & Result \\
\hline Hypothesis 1: & $\mathrm{H}_{1}$ : Customer experience has a positive impact on customer loyalty & Accepted \\
Hypothesis 2: & $\mathrm{H}_{1}$ : Employee behaviour has a positive impact on customer loyalty & Accepted \\
Hypothesis 3: & $\mathrm{H}_{1}$ : Value proposition has a positive impact on customer loyalty & Accepted \\
Hypothesis 4: & $\mathrm{H}_{1}$ : Relationship development has a positive impact on customer loyalty & Rejected \\
\hline
\end{tabular}

\section{Discussion of Results}

The main objective of the study was to understand the impact of CRM on customer loyalty in the context of small-medium enterprises, using the case of beauty centers in Beirut, Lebanon. The hypotheses in this study proposed that customer loyalty is dependent on the strategic implementation of CRM fundamentals, including: the customer's experience, the behaviour of employees, the value proposition, and relationship development. The results on these items confirmed our theory, in that CRM has a positive impact on customer loyalty. Customer experience, employee behaviour, and value proposition were the most essential elements in the formation of customer loyalty for customers of beauty centers in Beirut. The results were consistent with those of other literature. Customer-experience and value-proposition contributed the most according to regression results, indicating that customers count on a memorable journey, as well as quality interaction. This demonstrates how a meaningful and sincere connection between the customer and the supplier contributes to satisfaction, trust, and long-term loyalty, while poor experiences have the opposite effect, supporting the results of Shen \& Russell (2007), and Gartner (2001). Also, when the service is "customer centric", customers were more pleased, because things like fair price, quality service, and customization demonstrate that the enterprise places importance on their relationship, rather than on profit or marginal gains.

Moreover, it was proven that positive employee behaviour leads to positive customer loyalty. Since employees exhibit the most interaction with customers, especially in the service sector, they have a large impact on the creation and maintenance of customer relationships, lining up with theory from Peelen \& Beltman (2013). An employee that possesses the knowledge, courtesy, and responsiveness in line with the business's strategy will impact customer perceptions of the enterprise, as well as the likelihood of long-term relationships. Hence, the customer and the employee are inseparable entities. However, the degree of the relationship was contrary to that of Long et al., (2013), where employee behaviour held the greatest contribution towards customer loyalty in department stores in Tehran. Our results were less significant, however the dissimilarity could be associated with the difference in culture, population observed, and targeted sector. The results regarding the association between relationship development and customer loyalty was also unexpected. It was concluded that relationship development was not a direct predictor of customer loyalty, and this was consistent with the results of Long et al., (2013). However, the components that form this variable are still important to mention. First of all, the extent of conflict and feedback management could be influenced by the context of the situation. For instance, conflicts could have occurred but were solved before they manifested; or problems were discussed openly and customers disregarded them thereafter; and hence, an association was not declared. Furthermore, knowledge management using internal databases should be maintained in as many SMEs as possible. Our results indicated that a vast majority of the beauty centers already have a means of storing customer information internally, and make use of necessary customer knowledge. This was a good indication and should be continued, because in line with theory, an internal database provides crucial customer-insight necessary for developing appropriate solutions and facilitates effective interaction. Moreover, the existence or knowledge of a loyalty program within beauty centers was low, even though such a tool aids in the development of customer relationships, according to theory (Peelen \& Beltman, 2013).

Consistent with results of other literature, CRM presents the tools that are necessary to establish deeper relationships with customers, and create lasting relationships that are mutually beneficial. With a committed team perspective, and appropriate tools for managing customer knowledge, businesses can better understand customer needs and create better value propositions, which therefore, increase customer purchase behaviour.

\section{Conclusion}

\subsection{Recommendations}

Marketing research about the management of the beauty sector is almost absent in Lebanon. This paper is considered among the first to provide implications pertaining to the strategic management of SMEs through CRM. Hence, given their characteristics of being small, and therefore close to customers, this research can benefit many entrepreneurs in realizing that a customer-centric approach will provide their business a competitive advantage in a competitive industry, such as the beauty industry. Hence, SME owners should consider several initiatives, outlined as follows. One initiative is to establish a mentorship network. Potential 
SME owners can be matched with mentors from a local network of successful CEOs or other business owners who can provide guidance and advice to the entrepreneurs about best practices. In the context of developing potential entrepreneurs, there should be plenty of room for a female-led business environment. The development of women-entrepreneurs in Lebanon should be supported through committed policies, specialized training, as well as women-to-women support networks.

\subsection{Limitations}

The first limitation to this study was its reliance on snow-ball sampling. When administrating the questionnaire, the researcher was rejected by owners of beauty centers after requesting to share the facility for the purpose of data collection during hours of operation. Owners refused because of reasons related to privacy and potential disruption of their clientele. Hence, the dynamics of the sample involved could impose on the ability to generalize the results. Furthermore, results cannot be generalized to other parts of the world, since the study concentrated on only one sector in the Middle-East (Lebanon). Finally, the work in this study consisted of a quantitative examination only. However, a different approach such qualitative methods, like open or closed individual interviews, could have provided a wider understanding of customer perceptions or even management's decision-making mechanisms.

\subsection{Researcher's Perspective}

The previously mentioned limitations give attention to different avenues of research. These avenues concern the extension of this research and application of the model to other contexts. Future studies could be conducted outside of Lebanon to investigate the implications further. For instance, a comparative study could be done to take a further look into the differences of two different regions on the CRM practices that impact customer loyalty. Or, this type of study could be applied to other service organizations. In addition, the variables used in this study could be re-adapted or classified further, as some of variables could have multiple dimensions and relationships with other aspects. Future research could look into those specific areas. Lastly, qualitative techniques could be incorporated to supplement quantitative connotations.

\section{References}

Bobâlcă, C. (2013). Study of Customers' loyalty: Dimensions and Facets. Management \& Marketing Journal, $11(1)$.

Colgate, M. R., \& Danaher, P. J. (June 01, 2000). Implementing a customer relationship strategy: The asymmetric impact of poor versus excellent execution. Journal of the Academy of Marketing Science : Official Publication of the Academy of Marketing Science, 28(3), 375-387. https://doi.org/10.1177/0092070300283006

Fozia, R. N., Shiamwama, S. M., \& Otiso, K. N. (2014). Impact of Customer Relationship Management as a Strategy for Competitive Advantage in Kenyan Public Universities: A Case Study of Moi University. International Journal of Business, Humanities and Technology, 4. 1-10.

Gartner, Gartner Research. (December 13, 2001). Building Blocks of CRM: A Framework for Success. Retrieved from http://www.gartner.com/2_events/crmawards/2006/docs/buildingblocks.pdf

Harrigan, P., Ramsey, E., \& Ibbotson, P. (April 01, 2012). Exploring and explaining SME Marketing: Investigating e-CRM using a mixed methods approach. Journal of Strategic Marketing, 20(2), 127-163. https://doi.org/10.1080/0965254X.2011.606911

Inventis. (2014). Lebanon SME Strategy, http://www.economy.gov.lb/public/uploads/files/5910_8788_2242.pdf

Jamali, D. (2009). Constraints and Opportunities Facing Women Entrepreneurs in Developing Countries: A Relational Perspective. Gender in Management: An International Journal, 24, 232-251. https://doi.org/10.1108/17542410910961532

Khodakarami, F., \& Chan, Y. E. (2014). Exploring the role of customer relationship management (CRM) systems in customer knowledge creation. Information \& Management, 51(1), 27-42. https://doi.org/10.1016/j.im.2013.09.001

Kirmaci, S. (2012). Customer relationship management and customer loyalty; a survey in the sector of banking. International Journal of Business and Social Science, 3(3).

Long, C. S., Khalafinezhad, R., Ismail, W. K. W., \&Rasid, S. Z. A. (2013). Impact of CRM factors on customer satisfaction and loyalty. Asian Social Science, 9(10), 247. https://doi.org/10.5539/ass.v9n10p247

López, M. V., Fabrizio, M. C., \& Plencovich, M. C. (2014). Multiple Regression Analysis. Probability and 
Statistics: A Didactic Introduction, 416.

Ndubisi, N. O., Wah, C. K., \& Ndubisi, G. C. (, 2007). Supplier-Customer Relationship Management and Customer Loyalty: The Banking Industry Perspective. Journal of Enterprise Information Management, 20(2), 222-236. https://doi.org/10.1108/17410390710725797

Oliver, R. L. (2009). Whence Customer Loyalty? Journal of Marketing, 63, 33-44. https://doi.org/10.2307/1252099

Özgener, S., \& İraz, R. (January 01, 2006). Customer Relationship Management In Small-Medium Enterprises: The case of Turkish tourism industry. Tourism Management, 27(6), 1356-1363.

Peelen, E., \& Beltman R., (2013). Customer Relationship Management. United Kingdom: Pearson.

Piroozfar, S., \& Yaghini, R. (2012). A Review: Different Views of Customer Relationship Management.

Scarborough, N. M (2011). Essentials of Entrepreneurship and Small Business Management. New Jersey: Pearson.

Shen. J. C., \& Russell, K. H. C. (January 01, 2007). The Effects of Customer Relationship Management Practices and Multiple-Channels on Customer Loyalty in Financial Services. Asia Pacific Management Review, 12, 171-180.

Zikmund, W. G., Babin, B. J., \& Carr, M. G. (2010). Business Research Methods. Atlanta: Cengage Learning.

\section{Copyrights}

Copyright for this article is retained by the author(s), with first publication rights granted to the journal.

This is an open-access article distributed under the terms and conditions of the Creative Commons Attribution license (http://creativecommons.org/licenses/by/4.0/). 